\title{
Dariusz Brzostek
}

Dariusz Brzostek - teoretyk literatury, kulturoznawca, adiunkt w Katedrze Kulturoznawstwa UMK. Zajmuje się badaniem kultury popularnej, estetyki grozy oraz antropologii kontrkulturowej. Komentuje twórczość Stanisława Lema. Uprawia także sound studies oraz field recording. Autor monografii: Literatura i nierozum. Antropologia fantastyki grozy (Toruń 2009) oraz Nasłuchiwanie hałasu. Audioantropologia między ekspresją a doświadczeniem (Toruń 2014). 


\section{(Pop)kultura po rock and rollu. Uwagi o japońskiej muzyce eksperymentalnej}

DOI: http://dx.doi.org/10.12775/LC.2014.042

spółczesna japońska scena muzyczna jest, zarówno w kategoriach estetycznych, jak i kulturoznawczych, zjawiskiem osobliwym i osobnym. Nie jest to jednak efekt względnego i de facto pozornego egzotyzmu samej kultury japońskiej - tradycyjnej i popularnej - lecz złożonej historii powstania i rozwoju nowoczesnej muzyki w Kraju Kwitnącej Wiśni - uwikłanego w rozmaite dyskursy ideologiczne - estetyczne i polityczne, odciskające swe piętno na formach muzycznych, ich społecznej funkcji, obiegu medialnym, a także, last but not least, na kreacjach wizerunków oraz postawie artystycznej samych twórców. W tytule tego szkicu przedrostek „pop” w słowie popkultura został ujęty w nawias - nie jest to jednak li tylko efektowny chwyt retoryczny piszącego te słowa, lecz świadoma próba zwrócenia uwagi na niejednorodność tego fenomenu kulturowego, jakim jest kultura popularna w Japonii. Pomijając już tu wątpliwą zasadność podziału na to, co „masowe” i „artystyczne” w ponowoczesnych dyskursach kulturowych, trzeba jeszcze zaznaczyć, że omawiany w tym miejscu fenomen - „japońska muzyka eksperymentalna” z najwyższym trudem poddaje się tego typu klasyfikacjom, jakkolwiek bowiem znajduje swe dość wyraźnie dostrzegalne źródło w muzyce popularnej (jazz, rock and roll) oraz masowych ruchach społecznej kontestacji (kontrkultura lat 60. XX wieku), to jednak zdecydowanie przekroczył już zarówno „masowy”, jak i „popularny” (komercyjny) wymiar popkultury, stając się w istocie ekskluzywną formą (po)nowoczesnej ${ }^{1}$ awangardy muzycznej, zdominowanej przez takie kategorie estetyczne, jak „eksperyment”, „kolektywizm” (communitas), „minimalizm” czy „hałas”. Wszystkie one w istotnym stopniu kształtują również specyfikę japońskiej sceny eksperymentalnej.

1 I ten nawias znajduje swe uzasadnienie. Niektórzy z analityków ponowoczesności jako formacji kulturowej (np. Zygmunt Bauman) podają bowiem w wątpliwość samą możliwość istnienia „awangardy postmodernistycznej" - wiążąc tę formę artystyczną ściśle i bezpośrednio z modernizmem. Specyfika kultury japońskiej - i jej dość gwałtownej modernizacji oraz okcydentalizacji w XX wieku - sprawiła jednak, że "modernizm” i „postmodernizm” pojawiły się tam niemal równocześnie, jako różne (choć w Azji z trudem rozróżnialne) aspekty kultury zachodniej. Dla przykładu - kiedy Tatsumi Hijikata u schyłku lat 60. minionego stulecia "wymyśla” taniec butoh, odwołuje się wprost do doświadczeń europejskiego ekspresjonizmu, jednego z kanonicznych przejawów m o d e r n i s t y c z n e j awangardy. W tym samym czasie (1970) Sakuro "Kant" Watanabe organizuje w Japonii pierwszą komunę artystyczną - Maru Sankaku Shikaku, zorganizowaną na wzór amerykańskich gmin hipisowskich, wyznaczających neoplemienny zwrot charakterystyczny dla p o n o w o c z e s n o ś c i . 


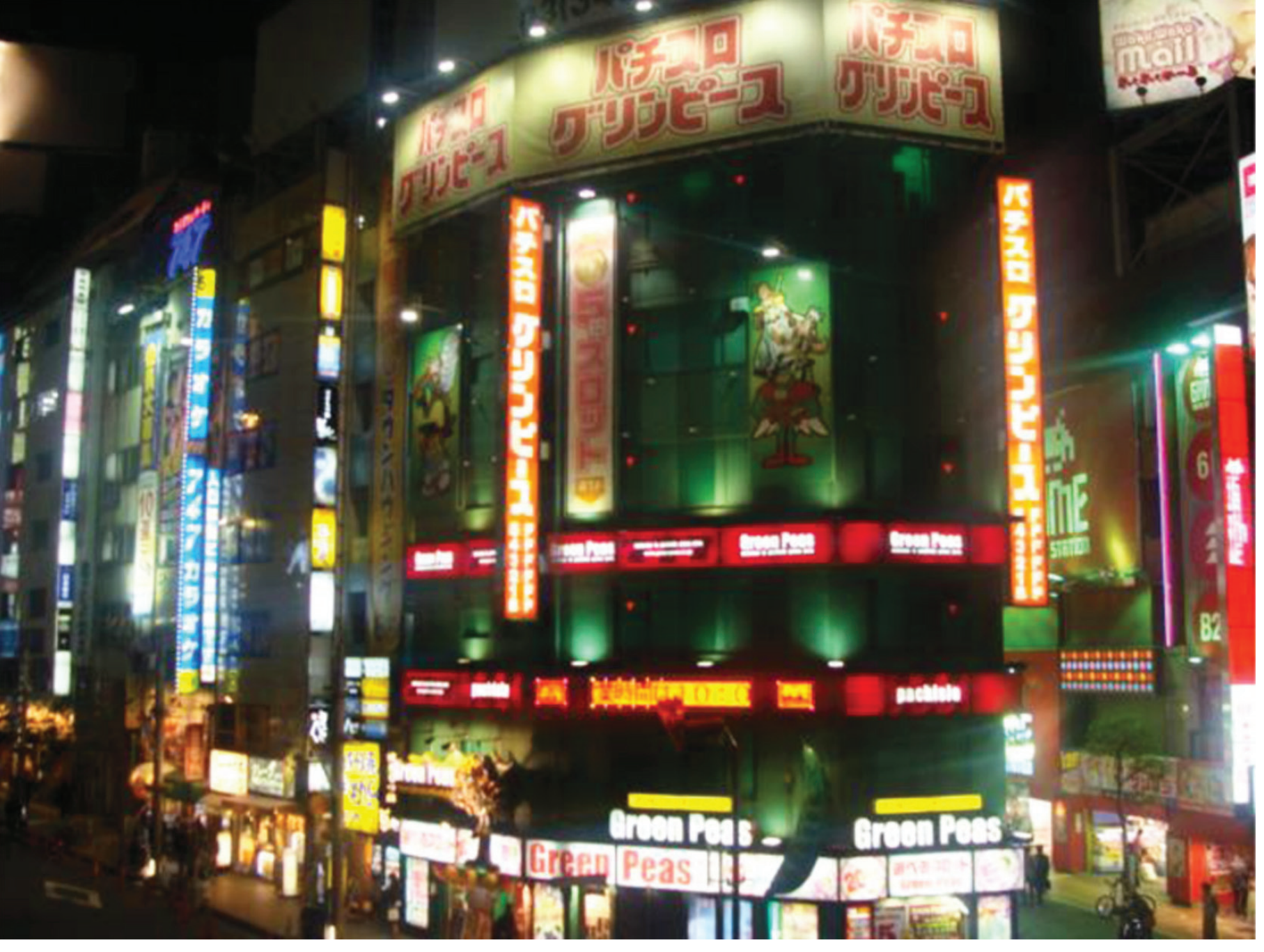

Tokio, Shinjuku, luty 2011 (fot. S. Kołos)

Aby uniknąć obszernych analiz samego pojęcia „eksperymentu” w sztuce i muzyce, jego związków z artystyczną awangardą, funkcji oraz technik, przywołam w tym miejscu koncepcję Michaela Nymana, który pisząc o muzycznych konsekwencjach przyjętej przez kompozytorów współczesnych „strategii eksperymentalnej”, odnotowuje, iż prowadzą one ostatecznie do ukonstytuowania się procesów stanowiących

[... najprostszy i najbardziej bezpośredni sposób zwyczajnego wprawiania dźwięków w ruch. Procesy są bezosobowe i zewnętrzne, więc nie prowadzą do organizacji dźwięków, ich integracji, tworzenia relacji harmonicznych, co jest udziałem naturalnej w wypadku ludzkiego umysłu skłonności do kontroli².

Dla sprecyzowania tej kategorii pozwolę sobie jeszcze przywołać opinię Bogusława Schaeffera, który zauważył niegdyś wnikliwie, że eksperyment w muzyce

2 M. Nyman, Muzyka eksperymentalna. Cage i po Cage’u, tłum. M. Mendyk, Gdańsk 2011, s. 47. Nyman podkreśla przy tym takie cechy charakterystyczne muzyki eksperymentalnej, jak ",spontaniczność", „otwartość na działanie przypadku” czy właśnie „procesualny”, a zatem „bezosobowy” charakter. 
powinien wiązać się z samą substancją muzyczną i niewątpliwie praca nad samym dźwiękiem [...], praca wewnątrzmateriałowa jest najbliższa współczesnemu eksperymentowi. Za eksperyment w pełni kompozytorski należy uznać taką formę p r ó b y s a m e go m a te r i a l u , która niweluje działanie poprzedniej kodyfikacji³ .

Tak scharakteryzowaną „muzykę eksperymentalną” będę traktował konsekwentnie jako swoisty punkt odniesienia oraz horyzont, którego historyczne wyłanianie się w kulturze Japonii stanie się tematem moich rozważań. Trzeba bowiem podkreślić, że japońska muzyka eksperymentalna (zwana niekiedy również „niezależną” lub „awangardową”) formowała się stopniowo w rozmaitych polach produkcji artystycznej i kulturowej - od akademickiej awangardy, przez formacje kontrkulturowe (Fluxus), aż po zjawiska usytuowane w samym centrum popkultury (jazz, rock and roll), przyswajając sobie niektóre ich cechy, jako integralne składniki własnej ekspresji artystycznej.

Kondycję japońskiego muzyka awangardowego („niezależnego”, „eksperymentalnego”) najlepiej charakteryzuje krótka odpowiedź Makoto Kawabaty (rockowego gitarzysty z grupy Acid Mothers Temple oraz śmiałego elektroakustycznego eksperymentatora $\mathrm{z}$ formacji Toho Sara) na pytanie o „różnice między japońską oraz europejską i amerykańską muzyką niezależną”, Kawabata odpowiada m.in.: „Od kiedy rock został importowany do Japonii nabawiliśmy się psychicznego kompleksu na punkcie muzyki Zachodu, łudząc się, że jakakolwiek produkcja muzyczna z USA czy Europy musi być lepsza niż muzyka japońska”4. Jest to wypowiedź niezwykle znamienna dla japońskich eksperymentatorów, jej ślady odnajdziemy także w odpowiedziach innych muzyków na podobne pytania: Shigetoshi Miyamoto wylicza zatem po prostu artystów, którzy na niego oddziaływali, wymieniając zarówno kompozytorów awangardowych (Cage, Young, Riley), muzyków jazzowych (Sun Ra, Eric Dolphy) i rockowych (Frank Zappa, Velvet Underground), zaś Yui Kimijima idzie jeszcze dalej, określając nawet procentowy udział owej inspiracji (np. „Jimi Hendrix: 8\%”) . Widać tu wyraźnie swoisty paradoks japońskiej „niezależności” muzycznej, która zdaje się mieć przede wszystkim charakter relacyjny. Oto artyści uprawiający sztukę nonkonformistyczną i eksperymentalną czują się w obowiązku określić sferę wpływów i oddziaływań, przyjmując za punkt odniesienia muzykę Zachodu, która może stać się przedmiotem afirmacji lub kontestacji, niezmiennie jednak zajmuje istotne miejsce, określając tożsamość japońskiego eksperymentatora - niezależnie od tego, czy on sam sytuuje się w świecie akademickiej awangardy, jazzowego eksperymentu, czy też rockowego undergroundu. Pozycja ta była oczywistą konsekwencją sytuacji społeczno-politycznej w Japonii po zakończeniu II wojny światowej - określonej w znacznym stopniu przez amerykańską okupację Wysp Japońskich i związaną z nią przyśpieszoną modernizację oraz stopniową okcydentalizację tradycyjnej kultury. Problem ten doczekał się szeregu wnikliwych omówień, by wspomnieć tylko prace Johna Dowera Embracing Defeat: Japan in the Aftermath of World War II ${ }^{6}$, Mariusa Jansena The Making of Modern Japan ${ }^{7}$ czy Yukiko Koshiro Trans-Pacific Racisms and the US Occupation of Japan ${ }^{8}$. Warto w tym miejscu przywołać jednak jeszcze jedną, niezwykle interesującą publikację Masao Miyoshiego: Off Center. Power and Culture

${ }^{3}$ B. Schaeffer, Mały informator muzyki XX wieku, Kraków 1987, s. 106. Podkreślenie D. B.

4 Japanese Independent Music, red. F. Stofer, Sonore 2001, s. 50.

5 Ibidem, s. 48-49.

6 Norton 1999.

7 Harvard University Press 2000.

${ }_{8}$ Columbia University Press 1999. 
Relations between Japan and the United States ${ }^{9}$. Książka zmarłego niedawno literaturoznawcy i socjologa poświęcona jest wprawdzie literaturze oraz amerykańskim i japońskim dyskursom krytycznoliterackim, wprowadza jednak bardzo ciekawy kontekst tej refleksji, umieszczając ją pośród rozlicznych odmian teorii postkolonialnej i wprowadzając, oprócz klasycznego antropologicznego pojęcia „różnicy kulturowej”, także (przejęte z pism Michela Foucaulta i Edwarda W. Saida) kategorie: „władzy”, „dominacji”, „hegemonii” czy wreszcie „przemocy” - wyzyskiwanych przez obie nacje w kreowaniu i/lub zacieraniu owej kulturowej odmienności, która je różni. Miyoshi wiąże przy tym kwestię amerykańskiej dominacji kulturowej z ekspansją wolnego rynku - organizującego także (w tradycji zachodniej) redystrybucję dóbr kultury - zyskującej w ten sposób wymiar masowy i (w konsekwencji) globalny. Zdaniem japońskiego badacza wiąże się to wprost z dziedzictwem europejskiego (i amerykańskiego) oświecenia wraz z jego kulturowymi, politycznymi i ekonomicznymi pryncypiami. W myśleniu Miyoshiego dają się więc wyraźnie zauważyć - niedeklarowane wprost - krytyczne tradycje „szkoły frankfurckiej” łączącej tradycje oświecenia z władzą i symboliczną dominacją oraz narodzinami kultury masowej ${ }^{10}$. W takim kontekście kultura popularna w powojennej Japonii staje się jeszcze jednym polem walki o symboliczną hegemonię. Jej atrybuty, takie jak jazz czy rock and roll, okazują się formami wypowiedzi o (także) politycznym charakterze i (bywa że) rewolucyjnej intensywności zaś zrodzona z nich muzyka eksperymentalna przyjmuje nierzadko postać (nie tylko) artystycznej transgresji.

Japońska muzyka eksperymentalna ma oczywiście swe źródła czysto akademickie, płynące z konfrontacji kompozytorów z tego kraju z wielkimi ideami modernistycznej awangardy europejskiej - głównie Schaefferowską koncepcją muzyki konkretnej, Cage’owskimi postulatami muzyki elektroakustycznej i estetycznego „oswajania hałasu” oraz odkryciem elektronicznych syntezatorów dźwięku (synteza granularna), które zainicjowało nurt muzyki elektronicznej (Xenakis). Japońska awangarda muzyki eksperymentalnej była związana głównie ze środowiskiem NHK Electronic Music Studio - założonego w roku 1955 jako lokalny odpowiednik słynnego niemieckiego studia Nordwestdeutscher Rundfunk w Kolonii (NWDR, istniejącego od roku 1954) ${ }^{11}$. Powstawały w nim najciekawsze, wczesne kompozycje „nowej muzyki japońskiej”: Musique concrète for stereophonic broadcast Minao Shibaty (1955), Sky, Horse and Death Toru Takemitsu (1958) czy Campanology for Electronic Music Toshihiro Mayuzumiego (1959). W owym czasie odbywają się także pierwsze festiwale „muzyki niezdeterminowanej” organizowane przez młodych twórców, takich, jak Toshi Ichiyanagi - zainicjowane 15 września 1961 roku - gromadzily debiutujących kompozytorów, wśród których znaleźli się m.in. Takehisa Kosugi, Yasunao Tone, Akimichi Takeda, Mieko Shiomi czy Nobutaka Mizuno. Jest to oczywiście muzyka inspirowana dokonaniami twórców zachodnich (Cage’a, Feldmanna, Wolffa, Browna), choć inkorporuje także elementy lokalne i tradycyjne (np. kompozycje Toru Takemitsu wykorzystujące skale dawnej muzyki japońskiej). Twórczość eksperymentujących kompozytorów pozostawała jednak - mimo swej rangi i wartości estetycznej - dość ekskluzywnym ekscesem artystycznej awangardy. Prawdziwie zmasowane

\footnotetext{
${ }^{9}$ Harvard University Press 1991.

${ }^{10}$ Klasycznym przykładem tej tendencji jest książka Maxa Horkheimera i Theodora W. Adorno, Dialektyka oświecenia. Fragmenty filozoficzne, tłum. M. Łukasiewicz, Warszawa 2010.

11 Wątki te śledzi wnikliwie Emmanuelle Loubet w swych interesujących szkicach: The Beginnings of Electronic Music in Japan, with a focus on the NHK Studio: The 1950s and 1960s, "Computer Music Journal" 1997, $\mathrm{nr} 4$ (21), s. 11-22 oraz The Beginnings of Electronic Music in Japan, with a focus on the NHKStudio: The 1970s, "Computer Music Journal" 1998, nr 1 (22), s. 49-55.
} 
uderzenie muzycznego eksperymentu miało nadejść z zupełnie innej, nieoczekiwanej strony.

Pierwszą, w porządku chronologicznym, formacją, którą można uznać za matecznik całej niemal japońskiej sceny muzyki eksperymentalnej lat 60 . minionego wieku była powołana do istnienia w roku 1958 Group Ongaku. Jej inicjatorami byli: aktywny w tokijskim środowisku artystycznym od końca lat 50. Takehisa Kosugi - w owym czasie - student Tokyo University of Arts i performer związany ściśle z japońskim odłamem Fluxusu oraz Shukou Mizuno. Specyfikę wystąpień Group Ongaku określał ich „nie-muzyczny” lub „anty-muzyczny" charakter, odwołujący się do Cage'owskich idei estetyki hałasu oraz aranżacji dźwiękowej otoczenia. Antymuzyka Grup Ongaku mieściła się dość dobrze w nurcie ówczesnych dokonań twórców Fluxusu - antymuzycznych działań Nam June Paika (One for Violin, 1962) i niemuzycznych kompozycji La Monte Younga (Draw a Straight Line and Follow It, 1960), zmierzając ku dekonstrukcji klasycznych form muzycznych, reprezentowanej często $\mathrm{w}$ aktach performatywnych destrukcją tradycyjnych instrumentów muzycznych bądź muzykowaniem na nie-instrumentach ${ }^{12}$. Można więc bez większego ryzyka uznać, że pierwszym impulsem dla narodzin japońskiej sceny muzyki eksperymentalnej były wystąpienia Fluxusu oraz (związane z nimi) praktyki takich artystów, jak John Cage, Nam June Paik, La Monte Young, Henry Flynt, C.C. Hennix, Peter Brötzmann czy Misha Mengelberg, z których wielu podtrzymywało ożywione relacje z awangardą japońską także po rozwiązaniu Fluxusu. Ze środowiska związanego z Group Ongaku wyłoniły się następnie dwie istotne formacje kontynuujące eksperymenty $\mathrm{z}$ awangardową, improwizowaną muzyką elektroakustyczną - określaną niekiedy mianem „metamuzyki”, ze względu na niezwykle istotny aspekt estetycznego organizowania przestrzeni dźwiękowej (sceny koncertowej, studia nagraniowego) jako integralnej części kompozycji. Zespoły te to Taj Mahal Travellers i East Bionic Symphonia. Istotą działalności Taj Mahal Travellers były wielogodzinne koncerty, podczas których Kosugi, Seiji Nagai, Ryo Koike, Yukio Tsuchiya, Tokio Hasegawa i Kinji Hayashi preparowali akustyczne instrumenty (kontrabas, skrzypce, trąbkę, perkusjonalia), amplifikując ich brzmienie i poddając je działaniu analogowych efektów elektronicznych (pogłos, echo etc.), w celu, który Peter Doyle trafnie zdefiniował w swej książce jako "fabricating space” (a więc „produkowanie przestrzeni”) ${ }^{13}$. Przełomowe znaczenie dla dokonań tej formacji miało bowiem swoiste uwolnienie muzyki od presji czasu i ścisłe jej powiązanie z kategorią przestrzeni, co kontynuowały z powodzeniem kolejne pokolenia japońskich eksperymentatorów, by wymienić tu tylko grupy East Bionic Symphonia i Mariginal Consort, której nagrania dokumentują muzyczne aranżacje przestrzeni w takich miejscach, jak Kotoku Morishita Bunka Center, Mikawadai Junior High School czy Asahi Square. Ten aspekt działalności japońskich eksperymentatorów wiązał ich dokonania z bliską Fluxusowi ideą „odzyskiwania przestrzeni miejskiej” oraz wyznaczał obszar konfrontacji koncertu muzycznego z rodzącą się w owym czasie sztuką instalacji dźwiękowych, usuwających nierzadko autora-wykonawcę poza sferę wydarzenia artystycznego ${ }^{14}$.

W tym nurcie mieszczą się doskonale również poszukiwania innego z adeptów Fluxusu, który jednak znaczną część swych idei muzycznych i performerskich zrealizował poza Japo-

\footnotetext{
${ }_{12}$ O muzycznych strategiach Fluxusu zob. D. Higgins, Muzyka z zewnątrz?, tłum. J. Holzman, [w:] idem, Nowoczesność od czasu postmodernizmu oraz inne eseje, wybór P. Rypson, Gdańsk 2000.

13 P. Doyle, Echo \& Reverb. Fabricating Space in Popular Music Recording 1900-1960, Wesleyan University Press 2005.

14 Zob. A. Licht, Sound Art. Beyond Music, Between Categories, New York 2007, s. 145-151.
} 
nią - w Europie i Stanach Zjednoczonych, stając się (obok Yoko Ono i Ikue Mori) jednym $\mathrm{z}$ bardziej rozpoznawalnych przedstawicieli japońskiej awangardy artystycznej w świecie Zachodu. Yoshi Wada - współpracownik La Monte Younga i uczeń indyjskiego mistrza śpiewu w tradycji Kirana Gharana - Pandita Pran Natha, był zarazem muzykiem, performerem, twórcą instalacji dźwiękowych i konstruktorem instrumentów muzycznych zainspirowanym ideami Harry'ego Partcha. Jego najsłynniejsze realizacje dźwiękowe: Earth Horns with Electronic Drone (1974) oraz Lament For The Rise And Fall Of The Elephantine Crocodile (1981) lączą elementy muzycznej performatyki (performing composer), konstrukcyjne innowacje instrumentów (preparacje i modyfikacje tradycyjnych aerofonów: kobzy, dud, trąbit) oraz twórczą interakcję z otoczeniem akustycznym (wyzyskanie potencjału brzmieniowego nieoczywistej przestrzeni koncertowej). Wada konsekwentnie wykorzystuje takie atrybuty przestrzeni, jak np. jej pogłos (pusty basen Media Study w Buffalo, sale Everson Museum of Art w Syracuse), eksponując w swych instalacjach nieskończenie długie dźwięki artykułowane z pełnym poszanowaniem akustycznej specyfiki otoczenia. Ten obszar muzycznych (oraz dźwiękowych) eksperymentów miał jeszcze charakter dość elitarny - stał się jednak istotnym punktem odniesienia oraz przedmiotem inspiracji dla muzyków jazzowych i rockowych.

Historia jazzu w Japonii (lub może - zależnie od przyjętej optyki - jazzu japońskiego) to, rzecz jasna, temat odrębny, dlatego też w tym miejscu warto przywołać tylko te jej epizody, które wiodły wprost do przekroczenia jazzowego idiomu i przejścia w sferę freely improvised music, co znamionowało narodziny „niezdeterminowanej” muzyki eksperymentalnej. Postacią ikoniczną dla japońsko-amerykańskiej fuzji jazzowej stała się z czasem Toshiko Akiyoshi, Japonka - urodzona w okupowanej Mandżurii i pianistka - grywająca w latach 50. z amerykańskimi jazzmanami w wojskowych klubach. Jej późniejsza kariera stała się swoistym synonimem sukcesu japońskiego jazzu w amerykańskim mainstreamie muzycznym i kulturowym. Przełomowe wydarzenia związane z pojawieniem się jazzu eksperymentalnego związane są jednak z artystami przywiązanymi do (również amerykańskiej!) tradycji freejazzowej, wśród których najważniejszymi postaciami okazali się po latach: Kaoru Abe, Motoharu Yoshizawa, Akira Sakata, Yoshisabiru Toyozumi, Mototeru Takagi i, przede wszystkim, Masayuki Takayanagi. Wszyscy wymienieni powyżej muzycy jazzowi stanowili przez lata trzon japońskiej sceny muzyki eksperymentalnej, kształtując jej swoistość w odniesieniu do takich przejawów (po)nowoczesnej awangardy, jak muzyka elektroakustyczna i swobodna improwizacja. Właśnie żywioł improwizacji - wyzwolonej najpierw z kanonów „ornamentacyjnej” improwizacji jazzowej, później z uwarunkowań czysto muzycznych (strój temperowany, instrument jako źródło dźwięku etc.) stał się głównym narzędziem artystycznego przełomu japońskich eksperymentatorów. Ich współpraca z najwybitniejszymi przedstawicielami europejskiej i amerykańskiej szkoły freely improvised music zaowocowała przyjęciem przez japońskich improwizatorów jazzowych swoistej „orientacji na eksperyment” oraz usankcjonowała obecność Japończyków na światowej scenie muzyki eksperymentalnej.

Najciekawsze i najbardziej znaczące wydarzenia w tej dziedzinie artystycznej wiążą się z działalnością Masayukiego Takayanagi, który najpierw wyprowadził muzykę jazzową poza obszar popkultury, by później zdekonstruować idiom jazzowego improwizowania, pozostając ostatecznie po prostu przy muzycznej improwizacji. Takayanagi - gitarzysta grywający jazz od lat 50. - debiutował w roku 1969 wydawnictwami płytowymi o charakterze freejazzowym - mieszczącymi się jednak doskonale w muzycznym kanonie tej stylistyki, by w ciągu kilku lat przejść na pozycję muzyka preferującego niezwykle śmiałą, intensyw- 
ną emocjonalnie i agresywną brzmieniowo improwizację. Najdobitniejszym świadectwem tego estetycznego przesunięcia jest zapewne album La Grima (2007), dokumentujący koncert tercetu: Takayanagi/Mori/Yamazaki na Genya Festival 14 sierpnia 1971 roku, będącym japońskim odpowiednikiem amerykańskiego festiwalu Woodstock, gromadzącym młodzież uczestniczącą w lokalnych ruchach kontrkulturowych ${ }^{15}$. Bezkompromisowa wypowiedź artystyczna grupy Masayuki Takayanagi New Direction for the Art wywołała wówczas konfuzję zaskoczonej publiczności, łamiąc nie tylko schemat piosenki rockowej (zwrotka-refren-zwrotka), ale także utarte wyobrażenia o jazzie i jazzowej improwizacji. Także kolejne wydawnictwa płytowe instrumentalisty (np. Action Direct: Live at Zojoji Hall 1985) usytuowały go ostatecznie pośród najwybitniejszych przedstawicieli elektroakustycznej muzyki improwizowanej, takich jak brytyjskie formacje AMM czy Spontaneous Music Ensemble, ujawniając zarazem nowe oblicze muzyki gitarowej, w którym instrument ten poddany mechanicznym oraz elektronicznym preparacjom służyć miał jako prosty, wyjęty z kontekstu tradycji muzycznej oraz popkulturowej, generator dźwięków.

Kolejne pokolenie japońskich improwizatorów jazzowych dorastało już zatem w „rzeczywistości odczarowanej”, w której jazz przestał być amerykańską muzyką popularną - przywiezioną na dodatek przez okupanta, a stał się niezwykle interesującym estetycznie instrumentem artystycznej transgresji. Najważniejszym przedstawicielem „nowej sceny” japońskiego jazzu stał się inny gitarzysta, Yoshihide Ōtomo, którego kolejne zespoły - Ground Zero czy New Jazz Ensemble, wkraczając śmiało w sferę eksperymentu (pozainstrumentalny hałas, muzyka elektroniczna, improwizacja elektroakustyczna), nieustannie odwoływały się także do jazzowej tradycji, traktowanej jednak nad wyraz plastycznie i postrzeganej w sposób niezwykle pojemny. Klasyczny album japońskiej awangardy muzycznej: Ground Zero Plays Standards przynosi (re)interpretacje pieśni Bertolta Brechta i Victora Jary, piosenek Burta Bacharacha („czytanych” jednak przez ich wersje z repertuaru Rolanda Kirka), ale także klasycznych pozycji „japońskiego jazzu” - autorstwa Kaoru Abe, europejskiej muzyki improwizowanej (Misha Mengelberg) i amerykańskiego rockowego undergroundu (Massacre), a nawet utwór japońskiej grupy rockowej Omoide Hatoba. Użycie w tytule płyty określenia „standards” - choć nie pozbawione ironicznego dystansu - sugeruje jednak wyraźnie, że polem odniesienia jest swoiście postrzegany kanon muzyki „słuchanej i wykonywanej w Japonii” ${ }^{16}$. Istotny wpływ na taką optykę interpretacji miała konfrontacja Yoshihide z jedną z kluczowych postaci nowojorskiej sceny jazzowej, Johnem Zornem, który zrealizował w Japonii - z lokalnymi muzykami, jeden ze swych niezliczonych projektów muzycznych: Cobra - łączący akustyczną muzykę etniczną $\mathrm{z}$ improwizacją ${ }^{17}$. Swój kolażowy charakter, skłonność do rekonstruowania oraz (nad)interpretacji tradycji oraz stylistyczny eklektyzm zawdzięczają kompozycje Yoshihide współpracy z amerykańskimi muzycznymi „postmodernistami”. Twórca ten jest jednak równocześnie jednym z najbardziej płodnych i kreatywnych artystów na japońskiej scenie muzycznej zaś jego kolejne projekty i wydawnictwa, m.in. Anode (2001) i Cathode (1999) należą niewątpliwie do

${ }^{15}$ Bezpośrednią przyczyną organizacji festiwalu był społeczny protest przeciwko rozbudowie lotniska Narita.

16 Zob. np. interesującą dyskusję opublikowaną w magazynie "Glissando": L. Komendant, J. Topolski, Dialog o serze i szynce, czyli o dwóch japońskich interpretacjach standardów, „Glissando. Magazyn o muzyce współczesnej" 2004, nr 1, s. 82-80 [numeracja odwrotna w druku - D. B.].

17 Niemal w tym samym czasie w Japonii realizował swój cykl koncertowy Conductions inny przedstawiciel amerykańskiej muzyki „ponowoczesnej”, Lawrence D. „Butch” Morris. Yoshihide wystąpił m.in. w jego kompozycji Conduction 50. 
najwybitniejszych osiągnięć tamtejszej awangardy, która zdecydowanie odrzuciła już tradycję jazzową, by na jej podstawie skonstruować własną formę muzyki eksperymentalnej. Dość podobnie przedstawiały się losy japońskiej muzyki rockowej.

Narodziny oraz „okres heroiczny” japońskiego rock and rolla opisuje interesująco i wnikliwie Julian Cope w swej popularnej, lecz gruntownie udokumentowanej, książce Japrocksampler. How the Post-War Japanese Blew Their Minds on Rock'n'Roll' ${ }^{18}$, skupiając przy tym uwagę także na kulturowych nieoczywistościach, jak choćby japońska kontrkultura narkotykowa czy polityczna ideologizacja muzyki rockowej w latach 70 . XX wieku. Warto więc w tym miejscu zwrócić uwagę, że pierwsza faza ekspansji muzyki rockowej w Japonii polegała, tak jak i w większości innych krajów - europejskich, afrykańskich czy azjatyckich ${ }^{19}$ - na dość wiernym, by nie rzec niewolniczym kopiowaniu wzorców angielskich i amerykańskich - w sferze muzyki, gadżetów oraz wizerunku gwiazd rock and rolla. Niezliczone lokalne „warianty” słynnych zachodnich grup rockowych - The Beatles czy The Rolling Stones, później zaś Led Zeppelin - nagrywały i koncertowały z powodzeniem od końca lat 60 . Świetnymi przykładami tej tendencji są choćby albumy zespołów The Mops (pod znaczącym tytułem Psychedelic Sounds in Japan, 1968) oraz The Happenings Four (Magical Happenings Tour, 1968), przynoszące po prostu japońskie wersje przebojów The Beatles, The Doors czy Jefferson Airplane. Stosunkowo wcześnie pojawily się jednak także formacje poszukujące osobnej (,japońskiej”) formuły wykonywania muzyki rockowej, odwołując się przy tym do innych niż anglosaskie dokonań w sferze rock and rolla (szczególnie do wpływowej sceny niemieckiej - z takimi grupami, jak Can, Amon Düül czy Faust). W takiej atmosferze rodziły się najbardziej znaczące dokonania japońskiego rocka - plyty: Vacant World (The Jacks, 1968), Ceremony: Buddha Meet Rock (People,1970), Red Buddha (Stomu Yamash'ta, 1971), Love Will Make a Better You (Love Live Life + One, 1971), Amalgamation (Masahiko Satoh, 1971), Alomoni 1985 (Karuna Khyal, 1974), Debon (Brast Burn, 1975) czy wreszcie nagrania hipisowskiej komuny Maru Sankaku Shikaku, wykraczające daleko poza stereotyp rock and rolla i sięgające po eksperymentalne techniki w sferze komponowania, improwizacji a nawet produkcji wydawnictw płytowych. Postacią niemożliwą do przeoczenia staje się w tym kontekście Taka’aki Terahara, ukrywający się pod pseudonimem J. A. Seazer - kompozytor muzyki filmowej i elektronicznej, twórca ścieżek dźwiękowych do eksperymentalnych, surrealistycznych filmów, które realizował w owym czasie Shuji Terayama. Twórczość J.A. Seazara - czerpiąca wprost z rocka i japońskiej muzyki popularnej nawiązuje zarazem do współczesnych jej dokonań musique concrète (której autorzy, np. Bernard Parmegiani czy Pierre Henry również chętnie flirtowali z rockiem). Eksperymenty Seazara ze studiem nagraniowym zapoczątkowały także, brzemienną w skutki, fascynację japońskich muzyków rockowych elektroniką.

Rock and roll jako matecznik japońskiej muzyki eksperymentalnej staje się tym bardziej przekonujący, jeśli uwzględni się bezkompromisową i pozbawioną precedensu działalność najważniejszej formacji muzycznego undergroundu lat 60. i 70. - Les Rallizes Dénudés (znanej także jako Hadaka no Rallizes). Zespół założył w roku 1967 na uniwersytecie w Kioto gitarzysta i wokalista Takashi Mizutani, otaczając się grupą muzykujących artystów związanych (od roku 1962) z lokalnym teatrem eksperymentalnym i deklarujących radykalne poglądy lewicowo-anarchistyczne. Światopogląd, ideologia (estetyczna i społeczna) oraz walka poli-

${ }^{18}$ Bloomsbury 2007

19 Pisałem o tym obszerniej w szkicu Rockin' All Over The World? Zarys muzycznej psychonawigacji, „Glissando. Magazyn o muzyce współczesnej" 2007, nr 13-14, s. 15-19. 
tyczna miały odegrać fundamentalną rolę w kształtowaniu swoistości artystycznej ekspresji Les Rallizes Dénudés - jej punktem kulminacyjnym stało się uprowadzenie w roku 1970 do Korei Północnej japońskiego samolotu pasażerskiego (Japan Airilines Flight 351), dokonane przez anarchistyczną grupę zbrojną, w której skład wchodził basista zespołu, Moriaki Wakabayashi. Wydarzenie to stało się „legendą założycielską” estetyczno-politycznego radykalizmu Les Rallizes Dénudés, zrastając się na stałe $\mathrm{z}$ wizerunkiem grupy (także za sprawą wydanej po latach płyty Flightless Bird. Yodo-Go-A-Go-Go, nawiązującej tytułem oraz oprawą graficzną okładki do tego dramatycznego incydentu). Wpływu zespołu Mizutaniego na japońską scenę eksperymentalną nie da się jednak sprowadzić do „czarnej legendy” terroryzmu, wniosła ona bowiem znacznie więcej - przede wszystkim tworząc zręby rockowego etosu (tak w sferze muzyki, jak ideologii) w kraju, w którym rock and roll był egzotycznym i ekscentrycznym zapożyczeniem z kultury popularnej Zachodu. Mizutani i jego muzycy od początku deklarowali wyraźnie podstawy swego światopoglądu społecznego i artystycznego, ujętego w kilka prostych punktów: żadnych kontraktów; żadnych wydawnictw płytowych; żadnych kompromisów artystycznych; koncerty to agitacyjne spektakle polityczne; muzyka jest nośnikiem radykalnych idei społecznych. Radykalizm ów stał się po latach jedną z najbardziej charakterystycznych cech japońskiej muzyki eksperymentalnej - niezależnie od tego, czy wyrażać się miał w estetyce noise, ekspresji rockowej, czy też w scenicznej celebracji kiczu ${ }^{20}$. Les Rallizes Dénudés - zespół rockowy, który ostatecznie przekroczył granice rock and rolla jako muzyki pop, czyniąc zeń instrument artystycznej i społecznej subwersji, pozostawił po sobie szereg nieoficjalnych (wydawanych przez fanów) koncertowych wydawnictw płytowych, skłonność do estetycznego ekstremizmu oraz „umiłowanie hałasu”, z którego narodziła się japońska awangarda muzyczna eksperymentująca z estetyką noise.

Miejsce szczególne w procesie uwalniania japońskiej muzyki eksperymentalnej od idiomu rock and rolla oraz wyprowadzania jej poza sferę popkultury ku obszarom zajmowanym dotąd przez artystyczną awangardę oraz kontrkulturę przypada jednak formacji Fushitsusha, powołanej do istnienia u schyłku lat 70. O ile wczesne nagrania tego rockowego tria (Live I) utrzymane są jeszcze dość wyraźnie w konwencji psychodelicznego rocka inspirowanego dokonaniami amerykańskich grup Grateful Dead i Blue Cheer, naznaczonego okazjonalnie elementami „estetyki hałasu” zapoczątkowanej przez The Velvet Underground, o tyle plyty późniejsze (Live II, Allegorical Misunderstanding) zdecydowanie porzucają już rockowy kanon, zachowując zeń wyłącznie instrumentarium (gitara, perkusja, gitara basowa) oraz elektryczną amplifikację brzmienia. Przechodzą one zdecydowanie ku formom „freely improvised music", bądź też zwracają się wprost ku stylistyce noise, wolnej od popkulturowego schematu piosenki, a także typowych dla rock and rolla konstrukcji rytmicznych i figur melodycznych. Zwłaszcza ostatni z wymienionych albumów, a także płyta Origin's Hesitation, zwracają uwagę dość zaskakującym połączeniem muzycznego minimalizmu (niemal punktualistyczne partie basu i perkusji) z ekspresją ufundowaną na eksploracji hałasu, jaki wytwarzają instrumenty elektryczne (sprzężenia, artykulacyjne zabrudzenia etc.). Lider grupy - gitarzysta i wokalista (w istocie zaś multiinstrumentalista), Keiji Haino, jest zarazem jedną z najbardziej wpływowych i znaczących postaci japońskiej awangardy muzycznej, choć przyznaje chętnie, że odpowiada mu określenie „bluesman”, zaś podstawowym źródłem inspiracji stało się dlań wysłu-

20 Przekonujących tego dowodów dostarcza choćby niezwykle interesujący dokument filmowy Cédrica Dupire We Don't Care About Music Anyway (2009). 
chanie utworu When The Music's Over grupy The Doors. Lista jego wydawnictw plytowych, artystycznych kooperacji oraz dokonań scenicznych jest niezwykle obszerna i naznaczona niebywałą różnorodnością - obejmuje bowiem zarówno adaptacje japońskiej muzyki ludowej (projekt Vajra), albumy z reinterpretacjami bluesa (Black Blues, 2004), bezkompromisowe studia nad akustycznym i elektronicznym hałasem (Twenty-first century hard-y guide-y man 1995; Watashi Dake 1981), jak i kameralne wydawnictwa solowe z muzyką swobodnie improwizowaną (na różnych instrumentach - Tenshi no gijinka, 1995 - metalofony; Global Ancient Atmosphere, 2005 - perkusja; Hikari Yami Uchitokeaishi Kono Hibiki, 2003 - gitara akustyczna) oraz wokalne adaptacje tradycyjnych pieśni. W centrum zainteresowań Haino niezmiennie jednak sytuują się ciało i głos - traktowane jako instrumenty ekspresji dźwiękowej. Jego sztuka, już od czasów debiutu z grupą Lost Aaraaf w roku 1970, ma charakter czysto somatyczny - odwołując się do pracy z oddechem (sięgającej korzeniami indyjskiej pranaja$m y$ ) oraz poszerzania artykulacji wokalnej o takie fenomeny głosowe, jak szept, jęk czy krzyk. Haino pozostaje przy tym przede wszystkim performerem - artystą działającym (i w głównej mierze improwizującym) na scenie, także we współpracy z innymi wykonawcami - muzykami (Peter Brötzmann, Derek Bailey, Bill Laswell, John Zorn) oraz tancerzami butoh.

W konsekwencji zaś na styku artystycznej awangardy oraz rozlicznych przejawów kultury popularnej (jazz, rock and roll) zaczęły pojawiać się z czasem w Japonii projekty i dzieła trudne do jednoznacznego zdefiniowania, tworząc w ten sposób specyfikę lokalnej muzyki eksperymentalnej. Warto wymienić tu dokonania tak egzotyczne, jak choćby album Asahito Nanjo Group Musica, Conteporary Kagura-Metaphysics (2004) przygotowany przez basistę rockowych grup Mainliner i Ohkami No Jikan, Asahito Nanjo, który wykorzystał tradycyjne azjatyckie receptury wróżbiarskie i alchemiczne jako wskazówki kompozytorskie do stworzenia monumentalnej kompozycji o niemal symfonicznym rozmachu, podążając tropem Johna Cage’a - sięgającego po chińską Księgę przemian - I Cing w swej praktyce kompozytorskiej (aleatoryzm). Nie mniej interesująca okazała się próba podjęta przez grupę Acid Mothers Temple, która na płycie In C (2002) przedstawiła własną wersję słynnej repetycyjnej kompozycji Terry’ego Rileya - zaaranżowanej na zespół rockowy, dodając od siebie dwa dodatkowe utwory: In E oraz In D. Lider tej formacji, Makoto Kawabata wydał także szereg płyt z repetycyjną muzyką gitarową - inspirowaną tradycją amerykańskiej szkoły minimalistycznej (Riley, Reich, Glass) oraz dokonaniami rockowego duetu Robert Fripp \& Brian Eno. Obaj wymienieni powyżej twórcy (Kawabata i Nanjo) współtworzą z kolei eksperymentalną grupę Toho Sara, której płyty stanowią doskonałe przykłady japońskiej szkoły eksperymentalnej muzyki elektroakustycznej, odwołującej się do koncepcji „długiego trwania dźwięku” i działań innego amerykańskiego minimalisty, La Monte Younga. Najciekawszym aspektem twórczości Toho Sara jest jej wyraziste zakorzenienie w tradycji azjatyckiej (japońskiej, ale także indyjskiej i koreańskiej), z której pochodzą m.in. akustyczne instrumenty muzyczne poddawane następnie preparacjom oraz elektronicznym modyfikacjom brzmieniowym. W podobnym nurcie mieści się interesująca płyta Brain Pulse Music (2012), której autorem jest Masaki Batoh - lider psychodelicznej grupy rockowej Ghost. Album ten powtarza w istocie - w zmodyfikowanej (zmodernizowanej) wersji - słynny gest amerykańskiego kompozytora Alvina Luciera, który w kompozycji Music for Solo Performer (1965) wystąpił na scenie podłączony do elektroencefalografu, używając fal mózgowych do wzbudzania drgań w sprzężonych z urządzeniem instrumentach perkusyjnych. Batoh wraca do tego konceptu, osadzając go jednak w nowym kontekście: po pierwsze używa tzw. Brain 
Pulse Machines - systemów przetwarzających fale mózgowe w sygnał akustyczny; po drugie umieszcza uzyskane w ten sposób nagrania w oprawie akustycznej skomponowanej na tradycyjne japońskie instrumenty perkusyjne i dęte o charakterze obrzędowym, wzbogacając w ten sposób Lucierowską wypowiedź na temat (nie)działania artysty o aspekt medytacyjny.

Znakiem rozpoznawczym japońskiej muzyki eksperymentalnej stała się jednak z czasem „estetyka hałasu” - określana zazwyczaj za pomocą angielskiego terminu noise. Źródeł tej fascynacji można dopatrywać się zarówno w estetycznych, programowych deklaracjach Johna Cage'a ${ }^{21}$ - piszącego w swym Credo:

Wierzę, że zastosowanie hałasu do tworzenia muzyki będzie stale wzrastało, aż zyskamy umiejętność wytwarzania muzyki przy pomocy instrumentów elektrycznych, co uczyni możliwym do wykorzystania dla celów muzycznych wszelkie i wszystkie dźwięki (any and all sounds), jakie można usłyszeće ${ }^{2}$.

Jak i w rockandrollowym fetyszyzowaniu elektryczności - symbolizowanym przez hałasującą gitarę elektryczną (Les Rallizes Dénudés, Fushitsusha). Nie można tu jednak pominąć - przewidywanej przez Cage’a - ekspansji instrumentów elektronicznych, które stały się źródłem (generatorem) pozamuzycznego (czy też nie-instrumentalnego) hałasu. W tym kontekście trzeba zatem odnotować pionierów japońskiej muzyki elektronicznej - łączących fascynację futurystycznymi syntezatorami dźwięków ze znajomością muzycznej tradycji Japonii oraz zanurzeniem w świecie muzyki pop. Najważniejszą postacią w tym nurcie pozostaje Magical Power Mako - twórca niebywale eklektycznych kompozycji, wiążących tradycyjną muzykę Japonii, elementy rocka, jazzu i swobodnej improwizacji z abstrakcyjną muzyką elektroniczną. Jego płyty Magical Power Mako (1973) oraz Super Record (1975) przez lata wyznaczały stylistyczną odrębność japońskiej muzyki elektronicznej, balansującej między popkulturą a dość radykalnym eksperymentem brzmieniowym ${ }^{23}$. Ekspansja (choć zapewne należałoby tu użyć określenia „eksplozja”) „muzyki hałasu” w Japonii przypada jednak na lata 80., gdy dostęp do elektronicznych syntezatorów dźwięku stał się powszechny, zaś „estetyka” popkultury została dość brutalnie skonfrontowana z „antyestetyką" takich ruchów kontrkulturowych, jak choćby industrial, postulujących radykalną krytykę popularnego kiczu i bezkompromisową dekonstrukcję artystycznych i rozrywkowych stereotypów kulturowych.

Najbardziej znaczącą postacią na japońskiej scenie noise jest bez wątpienia Masami Akita, występujący pod dadaistycznym pseudonimem Merzbow. Akita to w istocie człowiek-instytucja, autor kilkuset wydawnictw płytowych, w tym monumentalnego - Merzbox (2000) - zawierającego pięćdziesiąt autorskich albumów z próbkami czystego elektronicz-

${ }^{21}$ Związki Cage’a z Japonią są rozliczne i złożone. Obejmują zarówno głębokie zainteresowanie buddyzmem zen, inspirację sztuką japońską, jak i nagrania dokonywane w Japonii (kompozycja Ryoanji dedykowana "ogrodowi skalnemu" Ryoan-ji w Kioto).

22 J. Cage, The Future of Music: Credo, cyt. za: J. Luty, John Cage. Filozofia muzycznego przypadku, Wrocław 2011, s. 76-77.

${ }^{23}$ Do dziś najbardziej znanym i najłatwiej rozpoznawalnym japońskim autorem muzyki elektronicznej w popkulturze pozostaje oczywiście Kitaro - artysta, który w swej twórczości epatuje dość stereotypowym egzotyzmem, np. łącząc brzmienia syntezatorów z tradycyjnymi, akustycznymi instrumentami japońskimi. Jego popularność w świecie globalnej kultury pop staje się zrozumiała właśnie za sprawą tego wizerunkowego dopasowania do wyobrażeń ludzi Zachodu o Japończykach. Na tym tle Magical Power Mako może ze swą muzyką wydawać się - „nie dość japoński” lub paradoksalnie - „zbyt japoński”. 
nego i elektroakustycznego hałasu. Merzbow debiutował jako twórca abstrakcyjnych kolaży dźwiękowych konstruowanych przy użyciu prostych urządzeń elektronicznych i preparowanych instrumentów akustycznych, by następnie skupić się na analogowych i wreszcie cyfrowych źródłach dźwięków elektronicznych, łącząc przy tym wyraziste zaangażowanie ideologiczne (radykalna ekologia) z krytyką kultury popularnej (Akita z upodobaniem posługuje się np. „próbkowaniem”, czyli przetwarzaniem nagrań innych wykonawców). Nie mniej istotnym twórcą (anty)estetycznego hałasu jest Akifumi Nakajima (Aube), który wiąże estetykę noise z ascetyczną estetycznie ideą jednego (pozamuzycznego) źródła dźwięku, wykorzystując i poddając amplifikacji brzmienie takich „instrumentów”, jak lampy fluorescencyjne, woda, metal czy papier. W tym nurcie poruszają się także, nie mniej cenieni w Japonii i poza jej granicami, artyści jak K. K. Null, Takushi Yamazaki (Masonna) czy Kōji Tano (MSBR). Wszyscy oni eksploatują estetyczny potencjał dźwięków pozamuzycznych, podążając dość wiernie za dawnymi postulatami Johna Cage’a i Antonina Artauda, który fantazjował przed laty o instrumentach, „które mogłyby objąć nowy diapazon oktawy, wydawać dźwięki lub hałasy nieznośne, przeszywające”24.

Ponieważ jednak japońska muzyka eksperymentalna upodobała sobie skrajności, trzeba koniecznie odnotować także obecność najciekawszego być może zjawiska artystycznego ostatnich lat, jakim stała się tokijska scena Onkyōkei, której najważniejsi przedstawiciele: Toshimaru Nakamura, Taku Sugimoto, Sachiko M czy wreszcie Tetuzi Akiyama łączyli w swych wystąpieniach elementy elektroakustycznej improwizacji, muzycznego minimalizmu, muzyki sonorystycznej oraz estetyki hałasu ${ }^{25}$. Najbardziej charakterystycznymi cechami ekspresji muzycznej muzyków związanych z Onkyōkei była celowa redukcja głośności nagrań (ekspozycja dźwięków na granicy słyszalności) oraz eksponowanie ciszy jako podstawowego komponentu muzycznej kompozycji/improwizacji ${ }^{26}$. Do najważniejszych strategii twórczych muzyków tej sceny należy zaliczyć koncept „no-input mixing board” Nakamury - a więc wykorzystanie pozbawionej zewnętrznego źródła dźwięku konsoli mikserskiej jako instrumentu improwizacji (album Maruto, 2011), a także redukcjonistyczną postawę Taku Sugimoto - gitarzysty systematycznie ograniczającego swą muzyczną (dźwiękową) ingerencję w środowisko akustyczne koncertu, aż po ostateczny gest „nie-grania" (płyta Live in Australia, 2005). Radykalizm estetyczny muzyków Onkyōkei wydaje się w konsekwencji posunięty o wiele dalej niż najgłośniejsze ekscesy sceny noise.

Najlepszym zwieńczeniem refleksji przedstawionych w tym szkicu wydaje się przywołanie jeszcze jednej, dość ekscentrycznej, grupy eksperymentatorów - zespołu DJ-ów ukrywających się pod nazwą Satanicpornocultshop. Formacja ta wyspecjalizowała się w karkołomnym, plądrofonicznym ${ }^{27}$ miksowaniu globalnej muzyki pop w atrakcyjne (i w istocie nie mniej „popularne”) kolaże dźwiękowe, w których Lou Reed, Michael Jackson, Kylie Minogue, muzyka gamelanowa z Bali oraz ścieżki dźwiękowe z filmów Jana Švankmajera nakładają się na siebie współtworząc hybrydyczną i efemeryczną (muzycy Satanicpor-

\footnotetext{
${ }^{24}$ A. Artaud, Teatr Okrucieństwa (Pierwszy Manifest), tłum. J. Błoński, [w:] idem, Teatr i jego sobowtór, Warszawa 1978, s. 112.

${ }^{25}$ O scenie Onkyōkei pisał wnikliwie David Novak w szkicu Playing Off Site: The Untranslation of Onkyô, „Asian Music" 2010, vol. 41, nr 1.

${ }^{26}$ O retorycznej funkcji ciszy w muzyce swobodnie improwizowanej pisałem obszernie w tekście Patos hałasu i etos milczenia. Retoryka (swobodnej) improwizacji, „Fragile” 2011, nr 2 (12), s. 57-60.

27 O taktyce plądrofonii zob. Ch. Cutler, Plądrofonia, [w:] idem, O muzyce popularnej. Pisma teoretyczno-krytyczne, tłum. I. Socha, Kraków 1999.
} 
nocultshop chętnie improwizują), zawsze zaś fascynującą całość. W tej grupie działającej trochę na zasadzie „ożywionego samplera” ujawniają się zarazem najistotniejsze aspekty japońskiej muzyki eksperymentalnej: jej „założycielska” relacyjność względem europejskiej i amerykańskiej awangardy; nieuniknione uwikłanie w kulturę popularną - dostarczającą tworzywa artystycznego, ale i narzędzi ekspresji; napięcie między tym, co lokalne a tym, co globalne; estetyczny radykalizm i wreszcie poszukiwanie (osobliwej) tożsamości w (reinterpretowanej) tradycji śmiało ekstrapolowanej w (wyobrażoną) przyszłość. Najlepszą puentą tych rozważań będzie zaś (nie)pozbawiona znaczenia informacja, że grupa Satanicpornocultshop sporą część swych albumów wydała (po raz pierwszy i jedyny) w Polsce, w eksperymentalnym wydawnictwie plytowym Vivo Records, z siedzibą w Zambrowie. Oto ostateczne świadectwo „globalnej lokalności” (lub może „lokalnej globalności”).

\title{
Dyskografia
}

(ważniejsze wydawnictwa płytowe z japońską muzyką eksperymentalną)

\author{
Akaten \\ I, Magaibutsu 1995 \\ II, Magaibutsu 1995 \\ Aube \\ Hydrophobia, Vanilla 1991 \\ Luminous, G.R.O.S.S. 1993 \\ Métal de Métal, Manifold 1996 \\ Batoh Masaki \\ Brain Pulse Music, Drag City 2012 \\ Boredoms \\ Vision Creation Newsun, WEA Japan 1999 \\ East Bionic Symphonia \\ Recorded Live, ALM 1976 \\ Fushitsusha \\ Live, PSF 1989 \\ Live, PSF 1991 \\ Allegorical Misunderstanding, Avant 1993 \\ Origin's Hesitation, PSF 2001 \\ Gerogerigegege \\ Tokyo Anal Dynamite, Vis A Vis Audio Arts 1990 \\ Ground Zero \\ Ground Zero, God Mountain 1992 \\ Revolutionary Pekinese Opera Version 1.28, ReR 1996 \\ Plays Standards, Diw 1997 \\ Group Ongaku \\ Music of Group Ongaku, Hear Sound Art Library 1960/1961 \\ Haino Keiji \\ Watashi Dake, Pinakotheca 1981 \\ Tenshi no gijinka, Tzadik 1995 \\ Twenty-first century hard-y guide-y man, PSF 1995 \\ Hikari Yami Uchitokeaishi Kono Hibiki, PSF 2003
}

\section{9}


Tayu tayu to tadayoitamae kono furue, PSF 2004

Black Blues, Les Disques Du Soleil Et De L'Acier 2004

Global Ancient Atmosphere, PSF 2005

Ikeda Ryoji

+/-, Touch 1997

Kawabata Makoto

Osaka Loop Line, Acid Mothers Temple 1980/1981

Inui, Siwa 2000

Your Voice from the Moon, Vivo 2005

K.K. Null

Saishiyu Bushitsu, Nux Organization 1985

Kosugi Takehisa

Catch-Wave, CBS Sony 1975

Improvisation, Iskra 1975

Kousokuya

1st, Ray Night Music 1990

First Live 1979. Kichijoji Minor, PSF 2006

Les Rallizes Dénudés

Heavier Than a Death in the Family, Ain't Group Sounds 1995

Blind Baby Has It's Mother's Eyes, Japanese Rock 2003

Flightless Bird (Yodo-Go-A-Go-Go), 10th Avenue Freeze-out 2006

Le 12 mars 1977 a Tachikawa, Over Level

Live 1972, Over Level

Are You Rallizesed? Shizuoka Stupa 1974, Ignuitas 2007

Magical Power Mako

Magical Power, Polydor 1973

Super Record, Polydor 1975

Hapmoniym 1972-75, Mio Records 2004

Maru Sankaku Shikaku

Maru Sankaku Shikaku, Captain Trip 1973

Masonna

Shinsen Na Clitoris, Vanilla Records 1990

Merzbow

Music for Bondage Performance, Extreme 1991

Merzbox, Extreme 2000

MSBR

Ultimate Ambience, MSBR Records 1992

Nakamura Toshimaru

No-Input Mixing Board, Zero Gravity 2000

Maruto, Erstwhile Records 2011

Nanjo Asahito

Contemporary Kagura-Metaphysics, Fractal 2004

Otomo Yoshihide

Cathode, Tzadik 1999

Anode, Tzadik 2001

Ruins

Stonehenge, Shimmy Disc 1990

Sachiko M

Sine Wave Solo, Amoebic 1999

Satanicpornocultshop 
Anorexia Gas Balloon, Sonore 2003

Zap Meemees, Sonore 2005

J. A. Seazer

Kokkyou Junreika, Victor 1973

Den'en Ni Shisu, CBS/Sony 1974

Sugimoto Taku

Opposite, hatNoir 1998

Live in Australia, Improvised Music from Japan 2005

Taj Mahal Travellers

August 1974, Columbia Japan 1975

Live Stockholm July 1971, Drone Syndicate 2000

July 15, CBS Sony 1972

Takayanagi Masayuki

La Grima, Doubt Music 2007

Action Direct: Live at Zojoji Hall 1985, Tiliqua 2005

Toho Sara

Toho Sara, PSF 1995

Mei Jou Tan Sho, PSF 1999

Hourouurin, Fractal 2004

Tone Yasunao

Musica Iconologos, Lovely Music 1993

Tsunoda Toshiya

Extract From Field Recording Archive \#1, WrK 1997

Vajra

Tsugaru, PSF 1995

Ring, PSF 1996

Wada Yoshi

Lament For The Rise And Fall Of The Elephantine Crocodile, India Navigation 1981

Earth Horns with Electronic Drone, Omega Point 1974

Yamashita Stomu

Red Buddha, King Records 1971

Yokota Susumu

Acid Mt. Fuji, Sublime Records 1994

Image 1983-1998, Skintone 1998 